\title{
Logical and linguistic strategies for translating complex sentences in literary texts of natural languages
}

\author{
Tatiana V. Emets - Iuliia V. Baryshnikova - Alexey Yu. Trutnev - Elena V. \\ Suvorova - Tatiana L. Akhmetzyanova
}

DOI: 10.18355/XL.2018.11.02.01

\begin{abstract}
The relevance of the research is determined by the understudied inferences in the natural language (German and Russian) in the logical-linguistic aspect on the basis of complex sentences with subordinate conditional clauses. Research in this area will allow achieving a more holistic view of inferences in German and Russian both as a logical category and in a logical-linguistic aspect. In this connection, this article is aimed at revealing the fact how complex sentences manifest themselves in the German and Russian languages from the viewpoint of logical constructions. The objective of the research is to show that the analysis of the natural language by the methods of formal logic is possible and requires further careful study. In formal logic, a logical inference is a very complex phenomenon in terms of theoretical comprehension both in Russian and in German. The task is to show how the Germanspeaking authors construct logical inferences in the form of the German language and how these conclusions manifest themselves in the official translation into Russian. A complex methodology is used in the study including a method of continuous sampling while analyzing the empirical material, a statistical method, a descriptive method, as well as methods for linguistic and logical analysis of German and Russian complex sentences. The complex sentences from the original literary texts of the German authors of the 20th century and their official Russian translations provided the material for the research. Based on the conducted logical-linguistic analysis, the authors explain how logical inferences are represented in the literary Germanlanguage texts and consider logical and linguistic strategies of translation in the Russian-language texts. The significance of the study: The results of the analysis can contribute to the translation teaching theory and methods and actually to the practice of teaching the translation of German texts into Russian, in the process of studying the peculiarities of the language and style of German-speaking authors, and also in the compilation of machine translation programs for literary texts.
\end{abstract}

Key words: German, Russian, literary text, complex sentence, translation, formal logic, Modus BARBARA

\section{Introduction}

The problem of the relationship between the language and thinking in different angles has interested many researchers over a long period of time. However, the representative of domestic science, A.T. Krivonosov $(2012,2017)$ approached the study of the laws of interaction of the language and the logic of thinking closer than other scholars, in our opinion. Interaction of language and thinking, He explains this interaction from the logical and linguistic standpoints.

Scientific works of A.T. Krivonosov $(2012,2017)$ in the field of logical and linguistic analysis of the language served as a scientific basis for our study of complex sentences with subordinate clauses in the natural language. The statement of A.T. Krivonosov $(2012,2017)$ that language exists as an inseparable unity of the "logical forms of thought" and "semantic forms of thought" became the key to this study; as a

XLinguae, Volume 11, Issue 2, April 2018, ISSN 1337-8384, eISSN 2453-711X 
phenomenon in itself, it carries something from thinking under the term semantics. Two languages - logical and linguistic (semantic) - are considered in his works as a channel of internal communication between people. The obligatory presence of these two languages (i.e., thinking) is necessary for the appearance of the meaning of the sentence, the communication which is common for the speaker and the hearer. Krivonosov also assumes that the study of semantic meanings in natural language (the first, lower stage of semantic abstraction) can no longer be considered complete without using logical methods for analyzing the natural language (the second, higher stage of semantic abstraction). This research is devoted to the study of logical and linguistic strategies for the translation of complex sentences in the literary texts of natural languages (German and Russian) and attempts to show that the analysis of the natural language by the methods of formal logic is both admissible and possible, and "there is really something in this".

In other words, the article investigates complex sentences with conditional clauses in German, and their equivalents in Russian from the viewpoint of formal logic and causative-consecutive relations are applied to all semantic meanings (syndetic and syndetic complex sentences with subordinate conditional clauses in the German and Russian languages). The semantic basis of complex sentences with subordinate conditional clauses includes two kinds of logics: the logic of predicates which is a simple categorical syllogism and the logic of utterances which is a conditionally categorical inference. The inferences as for the most complex, least studied in linguistics are chosen from the known forms of thought (concepts, judgments, inferences). Based on the material of the natural language (German and Russian), the connections between the structure of the language and the higher logical forms of thought (inferences) are consistently revealed in an empirical way. The authors face the task of showing how a person thinks - builds inferences in the forms of the natural language (in the forms of complex sentences).

\section{Literature Review}

The review of the scientific literature shows that the science of language knows fundamentally different approaches to the study of a sentence (a complex sentence) as a syntactic unit. When comparing different attempts to define the sentence, the main tendencies are revealed:

- to find purely linguistic criteria in the approach to the sentence;

- to define the sentence with the help of non-linguistic methods (logical, logical and psychological, etc.).

The studies devoted to complex sentences with subordinate conditional clauses differ greatly from each other in specific tasks, and general theoretical concepts, from the standpoint of which the linguists approach the research of these constructions. Many academic papers dealing with the study of complex sentences in the Russian and European languages were created within the framework of the national, linguistic tradition. The works by T.V. Emets (2012), O.V. Evstafiadi and U.S. Baymuratova (2015), V.V. Babaitseva (2015), N.N. Fattakhova (2015), L.V. Bednarskaya (2015), and B.A. Abramov (2016) should be noted among the most recent transactions. Foreign studies are also notable for the breadth of the material being researched, the interest in logical, cognitive, logical-cognitive investigations, but they do not consider the causative-consecutive relations in sentences in the context of logical-grammatical analysis (Chang,Janciauskas\&Fitz, 2012; Szymanik\& Verbrugge, 2013; Pagnan, 2013; Searle, 2014; Mackenzie, 2014; van Benthem, 2014; Dekker, 2015; Beni, 2015; Mahowald et al., 2016;Dubois, Prade\&Schockaert, 2017).

Much less attention is paid to the problem of logical-linguistic analysis of causativeconsecutive constructions. The recent monograph devoted to the logical-grammatical 
mechanisms in the text (in the complex sentences) belongs to T.V. Emets, N.R. Urazaeva and Y.V. Baryshnikova (2017). Some researchers also consider that the study of the natural language by formal logical methods raises some questions (Zayats, 2017). But, nevertheless, currently, the study of various syntactic constructions in terms of formal logic attracts increasing attention. The emerging questions can be answered, supported by numerous examples, for instance, from the literary texts.

\section{Materials and Methods}

The original literary works of the German authors of the $20^{\text {th }}$ century: A. Seghers (1951), S. Wolf (1960), J.R. Becher (1950, 1970), W. Bredel (1952, 1964), W. Kellermann (1962, 1979), W. Uhse (1969), D. Noll (1981) were used as an empirical material of the study. These texts were translated by Russian writers and translators N.G. Kasatkina and V.O. Stanevich (1989), I.N. Karintseva and N.G. Kasatkina (1964), I.A. Gorkina (1970), R.A. Rosenthal (1964), Z.A. Vershinina (1979), A.A. Nebenzia and V.G. Litvinets (1987), R.M. Galperina and V.N. Kurella (1963). The choice of texts was dictated by the prototypical nature of the literary works, the variety of forms of complex sentences with subordinate conditional clauses presented in these texts.

A comprehensive methodology is applied in the study, including a method of continuous sampling in the analysis of the empirical material, a statistical method, a descriptive method and methods of linguistic and logical analysis of German and Russian complex sentences. The method of continuous sampling involves the collection of linguistic material: 2107 complex sentences with conditional clauses were identified in the German texts (a total of 3,763 pages), and corresponding translation suggestions were revealed in the Russian texts. The statistical method allows establishing the numerical characteristics of complex sentences with subordinate conditional clauses (syndetic and asyndetic ones), expressing or not expressing inferences in the German and Russian languages. Complex sentences are systemized and characterized; the logical and linguistic originality of the material under study is described by means of the descriptive method. The methods of linguistic and logical analysis of German and Russian complex sentences enable to study the ways of expressing inferences of the same content having a certain logical form with the means of two languages; to analyze the linguistic expression of the logical structure in one of the languages (German) and to compare it with an official translation of complex sentences with subordinate conditional clause into Russian. The study of the linguistic material is conducted at two levels: logical and linguistic ones.

When analyzing the linguistic material at the logical level, it is expected to reveal:

- whether complex sentences with subordinate conditional inferences presented in German are retained in the Russian translation;

- if the inferences are retained, the modus of inferences is identified (whether the modus is retained or it is replaced by another one), and the model of the modus is determined (whether the sequence of judgments in the inferences of the original text is retained or it is changed during translation).

The analysis of the linguistic level will enable to reveal:

1. which syntactic constructions of the Russian language implement the inferences that are expressed in the German language by complex sentences with subordinate conditional clauses.

XLinguae, Volume 11, Issue 2, April 2018, ISSN 1337-8384, eISSN 2453-711X 
2. the ways of translating conditional conjunctions, which are the linguistic means of expressing complex sentences with subordinate conditional clauses at the level of the language and, at the same time, formal logical markers at the level of logic.

Thus, both the logical and linguistic levels are examined in close interaction as a kind of logical and grammatical unity, and it is supposed to prove the following:

1. Russian complex sentences with subordinate conditional clauses which are based on a semantic causative-consecutive or conditional-resultative relationship between the subordinate and principal clauses as well as German complex sentences serve as a means of expressing deductive inferences in the form of enthymemes;

2. Russian complex sentences with subordinate conditional clauses also have certain semantic and syntactic features, depending on the type of logic, modus and the model of expressed inference;

3. In most cases, Russian sentences, being equivalents of German sentences expressing inferences, preserve inferences of the same modus and model of the original text, which testifies to the universal logical and grammatical unity in different languages;

4. Part of inferences expressed by complex sentences of the German language acquire a different degree of clarity and certainty of these inferences in the corresponding equivalent constructions of the Russian language, which is related to the specific features of the literary translation and the deviations made by the translator.

The linguistic analysis of the empirical material shows that the subordinate clause can be in preposition, postposition, and interposition with regard to the principal clause.

Preposition: (2) Wenn ich ins Theater gehe, (3) soll ich die Karte kaufen. Postposition: (3) Ich soll die Karte kaufen, (2) wenn ich ins Theater gehe. Interposition: (3) Ich soll, (2) wenn ich ins Theater gehe, (3) die Karte kaufen.

From the logical standpoint, these examples provide with three models for constructing complex sentences with subordinate conditional clauses, where (2) is a conditional clause (a 'smaller premise' from the position of formal logic), (3) is the principal clause (a 'conclusion'):

the $1^{\text {st }}$ model: (2) - (3) - the condition (a smaller premise) precedes the consequence (a conclusion);

the $2^{\text {nd }}$ model: (3) - (2) - the consequence (a conclusion) (3) precedes the condition (a smaller premise) (2);

the $3^{\text {rd }}$ model: (3) - (2) - (3) - the smaller premise (2) occupies the interposition, breaking the consequence (the principal clause), which occupies the transposition.

For a more complete picture, it is necessary to explain how this type of sentences is expressed in the forms of logical inferences and to consider the relationship between the concepts of the language and logic:

An inference (syllogism) consists of (1) a major premise, (2) a minor premise and (3) a conclusion. The varieties of syllogisms of the same figure, determined by different quality and quantity of premises and conclusions, are called moduses. In formal logic, 19 correct moduses were proved in the four figures of a simple categorical syllogism. For the purposes of our research, it turned out to be sufficient to use only three moduses of the first and second figures. These are BARBARA, CELARENT, and CAMESTRES moduses.

In a natural language, complete syllogisms are practically not used but are implemented in a reduced form, either with a premise or a conclusion omitted. These reduced syllogisms are called enthymemes ('what I keep in mind'). According to the research by A.T. Krivonosov (2017), in scientific and literary speech inferences are used most often in the form of enthymemes. The cumbersome schemes, which are given in the textbooks of the logic, as examples of inferences, almost never occur in the language. Self-evident and axiomatic general judgments which are based on the 
vast - human experience, i.e., major premises, are eliminated in the inferences expressed by complex sentences. These sentences possess certain semantic and syntactic features, depending on the type of logic, modus and the model of the expressed inference. The analysis of complex sentences revealed also a number of sentences that did not express inferences for one reason or another, which indicates the intentions of the authors of the works of art and proves that the natural language (German and Russian) is much more versatile than the formulas of formal logic; it is not limited to logical moduses. However, it is impossible to deny that logical mental constructions are an integral part of a human cognitive apparatus, therefore in this paper, the authors' attention is attracted by sentences expressing inferences.

According to the data obtained using the material of natural languages, the ratio of the amount of 'text' represented by complex sentences expressing and not expressing inferences is $87 \%: 13 \%$ in the German text (being 83\%:17\% in Russian equivalents). Consequently, it is the literary text, stating anything but scientific reasoning, which requires the speaker (writer) to follow strict consistency, persuasiveness, and logic in communicating the thought. Complex sentences have two varieties: 1) sentences with the real condition (they use the form of the present and past tense in the syntactic indicative, the subjunctive mood); 2) sentences with a surreal, desired or assumed condition (they use the future tense forms in the subjunctive mood). The former is considered by the logic of predicates, the latter by the logic of utterances.

A man, using the 'spontaneous' thinking, makes inferences only by the rules of the logic of predicates and utterances, that is, the entire wealth of his thoughts and linguistic forms to express them (complex sentences) can fit only in three moduses (BARBARA, CELARENT, CAMESTRES). Inferences, expressed by complex sentences, are translated into Russian by the most diverse syntactic constructions: 1) a complex sentence (complex, compound, asyndetic complex one); 2) the sequence of two independent sentences; 3) a simple sentence with various complications.

The variety of syntactic forms intended to express inferences is evidence of the fertility of the natural language, which has synonymous means for expressing inferences. The degree of clarity of this or that syntactic construction in the expression of logical inferences depends on: a) the presence or absence of formal means for expressing conditional relations (they serve as the formal markers of algorithms for constructing syllogisms) and b) the completeness of explication or contraction of the inferences underlying this or that construction.

Thus, there are special constructions (complex sentences with subordinate conditional clauses) in the language that are used to express logical enthymeme with a missing major premise. In these enthymemes, the sequence of judgments can be of two kinds: a) a 'correct' sequence, that is, (2) a minor premise - (3) the conclusion (as in logic), b) a 'wrong' sequence, that is, the sequence contradicting correct logical constructions, namely: (3) the conclusion - (2) the minor premise or (3) - (2) - (3). This means that in the second case (b) the speaker expresses the conclusion (consequence) of the syllogism at first and only then selects an appropriate justification (a minor premise) for his/her conclusion.

Therefore, to restore the enthymeme correctly in a complete inference, the following steps were taken:

1) Recognition of inferences in the text (in the complex sentences with subordinate conditional clauses).

2) Determination of the form of inferences (modus, figure, enthymematic models),

3) Linguistic characterization of inferences (enthymemes):

a) Dividing complex sentences expressing enthymemes into syndetic and asyndetic clauses, then according to the corresponding conjunctions.

XLinguae, Volume 11, Issue 2, April 2018, ISSN 1337-8384, eISSN 2453-711X 
b) Comparing the ways of expressing inferences in German with their translation into Russian.

The empirical material in this work is represented by linguistic constructions expressing a syllogism in the form of an enthymeme with a missing major premise. In this regard, the procedure for restoring a complete inference by its enthymeme is part of the general procedure of logical and linguistic analysis, which forms the basis of our study. To describe this procedure, let us use the following notations: a major premise, a minor premise and a conclusion of the syllogism are marked by the numbers in parentheses (1), (2), (3), respectively. The major premise that is missing in the enthymeme is placed in square brackets. Formal linguistic means indicating the condition (a 'minor premise'), the categorical judgment (a 'conclusion'), as well as formal linguistic means indicating the presence of negative modus (negative formants) are underlined.

When comparing inferences in the forms of the German and Russian languages, the authors considered "Russian" inferences from the viewpoint of their translation into Russian. Therefore, after each German example, its official translation into Russian is given, sometimes, if necessary, the enthymeme is unfolded into the complete inference.

The empirical material of the German language also makes it possible to see how conditional conjunctions (wenn, falls) with the same meaning, which are the strongest markers indicating the condition (ground) and result, "work for logic". A subordinate clause with wenn (if) is a reason (a minor premise); hence, a principal clause is a consequence (conclusion).

The analysis of all complex sentences is beyond the scope of the article; therefore, sentences, represented by the enthymemes of only one BARBARA modus of the model (2) - (3) (358 examples) in German and their Russian equivalents were considered in detail.

BARBARA is the conventional name of the first modus of the first figure of a simple categorical syllogism, in which the three vowels $(\mathrm{A}, \mathrm{A}, \mathrm{A})$ in its name indicate that all three judgments (a major premise, a minor premise, and a conclusion) are general affirmative judgments. A classic example of this modus is:

(1) All predatory animals eat meat.

(2) Lions (S) are predatory animals.

(3) Lions (S) eat meat.

Let us exemplify the above by the literary text of the German and Russian languages:

(2) ...und wenn ein Dienstbote nur eine Miene verzog, (3) so setzte sie ihn vor die Tür (Kellermann, 1962) In the translation: (2) А если кто-нибудь из служанок делал недовольную мину, то ее тут же выставляли за дверь [And if anyone of the maids made a wry face, then she was kicked out at once] (Vershinina, 1979: 259).

Let $s$ analyze this sentence:

In terms of linguistics, this is a complex sentence with a subordinate conditional clause in the preposition both in German and Russian.

In terms of logic, this is an enthymeme of BARBARA modus, the model (2) - (3), where (2) is a subordinate conditional clause with the conjunction IF (a 'minor premise' from the standpoint of formal logic), (3) is a principal clause (a 'conclusion' from the standpoint of formal logic). The missing major premise (1) is reconstructed by the 'minor premise' (2) and 'conclusion' (3): (1) [Everyone who made such a face was kicked out]. Since the major premise was restored, this is an enthymeme (an incomplete inference) of BARBARA modus. Consequently, the above complex sentence, containing two general affirmative judgments, which is an incomplete logical syllogism (enthymeme), is built according to the rules of the general 
affirmative modus BARBARA with the sequence of judgments (models) (2) -

(subordinate conditional clause - principal clause) .

Any enthymeme, represented in the German and Russian languages by complex sentences, is restored to the complete inference in a similar way. Each modus has its own procedure for the restoration of the enthymeme to a complete syllogism, as has been repeatedly indicated in the works by A.T. Krivonosov $(2012,2017)$, T.V. Emets (2012), T.V. Emets, N.R. Urazaeva, and Y.V. Baryshnikova (2017).

\section{Results}

Let us consider the ways of translating the enthymeme of BARBARA modus, model (2)-(3) into Russian, where (2) is a subordinate conditional clause with or without a conjunction (a 'minor premise' from the standpoint of formal logic), (3) is a principal clause (a 'conclusion' from the standpoint of formal logic).

The enthymemes of BARBARA modus, model (2)-(3) (358 examples in total), expressed in German by complex sentences both subordinate conditional clauses, have been translated into Russian by means of various syntactic constructions and represented by the enthymemes of the following moduses:

1) BARBARA models (2)-(3) (333 examples in total);

2) BARBARA models (3)-(2) (5 examples in total);

3) BARBARA (3)-(2)-(3) (10 examples in total);

4) CELARENT models (2)-(3) (6 examples in total);

$5)$ an inference was not retained in four sentences during translation.

Let us consider attentively each of the obtained groups:

1) Modus BARBARA and model (2)-(3) (333 examples in total) are retained.

Syntactic constructions:

a) complex sentences:

Conditional conjunctions (wenn, falls) in the Russian translation are notable for the variety of conjunctions, syndetic words and correlates, such as IF ... THEN, WHEN ... THEN, GIVEN, WHILE, THEN, NO SOONER ... THAN, AS SOON AS.

- IF ... THEN: (2) ...und wenn ein Dienstbote nur eine Miene verzog, (3) so setzte sie ihn vor die Tür (Kellermann, 1962) - (2) А если кто-нибудь из служанок делал недовольную мину, то ее тут же выставляли за дверь [And if anyone of the maids made a wry face, then she was kicked out at once] (Vershinina, 1979: 259).

b) syndetic compound sentences:

(2) Wenn die Lehrer in den Wohnbaracken unterrichteten, (3) quälte man sich über die drei Stunden hinweg... (Noll, 1981) - (2) Уроки в бараках отбывали через силу, (3) и все три часа прилежные ученики только и ждали боевой тревоги [The lessons in the barracks were listened with an obvious effort, (3) and for all three hours the diligent pupils were just waiting for a military alarm... (Galperina \& Kurella, 1963).

c) asyndetic complex sentences:

(2) Wenn du mir sagst, er ist ein abständiger Kerl, (3) glaub ich dir das aufs Wort. (Wolf, 1960) - (2) Tы говоришь, он приличный человек, (3) я верю тебе [You say he's a decent person, (3) I believe you] (Karintseva \& Kasatkina, 1964).

d) two independent sentences with various connectors: BECAUSE, WHERE:

(2) Wenn ich dem Staat diene, (3) so deshalb, weil der Staat das Allerhöchste ist. (Becher, 1950) - I serve the State, (3) because the State is above all... (Gorkina, 1970).

e) simple sentences:

- with prepositional substantive phrases: (2) Wenn er an sie dachte, (3) überfiel ihn eine seltsame Schwäche (Bredel, 1952) - (2) При мысли о ней (3) Вальтером

XLinguae, Volume 11, Issue 2, April 2018, ISSN 1337-8384, eISSN 2453-711X 
овладевала какая-то странная слабость. [At the thought of her (3) Walter was possessed by some strange weakness] (Rosenthal, 1964: 296);

- with an adverbial participial construction: (2 examples in total) Wenn Harteneck an seinen Gegner dachte, (3) empfand er eine Art widerwilligen Respekts. (Uhse, 1969) (2) Думая о своем противнике, (3) Хартенек волей-неволей испытывал даже что-то вроде почтения.[Thinking about his opponent, (3) Harteneck, willy-nilly, experienced even a sort of reverence] (Nebenzia \& Litvinets, 1987: 305).

2) Modus BARBARA is retained when translated into Russian, though the enthymematic model is changed from (2)-(3) to (3)-(2) (5 examples in total) and the following syntactic constructions are used:

a) a complex sentence with if-clause:

(2) Falls je noch einmal vom Weggehen die Rede sein könnte, (3) müBten Sie rechtseitig weg. (Seghers, 1951) - (3) Мой вам совет - уезжайте заблаговременно, (2) если дела пойдут совсем плохо. [My advice to you is leave in good time, (2) if things go wrong] (Kasatkina \& Stanevich, 1989: 511).

b) an asyndetic complex sentence:

(2) Wenn du glaubst, (3) du kannst nicht (Bredel, 1952) - (3) А не можешь, ну что ж! [You can't, OK, then] (Rosenthal, 1964: 354).

3) Modus BARBARA is retained when translated into Russian, model (2)-(3) is changed by (3)-(2)-(3) (10 examples in total), with the following syntactic constructions:

Syndetic complex sentence:

- IF: (2) Falls es doch noch mit seinem Bruder schiefging, (3) mußte er seinen Anteil sucherstellen für jetzt und für immer. (Seghers, 1951) - (3) На случай, (2) если $c$ братом что-нибудь приключится, (3) нужно ему ... раз и навсегда обеспечить свою долю[In case, (2) if something happens to his brother, (3) he needs ... to ensure his share once and for all] (Kasatkina, Stanevich, 1989: 281).

- WHEN: (2) Wenn der Vater so mit sich selbst sprach, (3) nahm er eine rauhe Stimme an... (Becher, 1950) - (3) Голос у отиа, (2) когда он вел эти разговоры с самим собой, (3) сразу грубел... [The voice of his father, (2) when he held these conversations with himself, (3) immediately grew rude] (Gorkina, 1970: 498).

- NO SOONER... THAN: (2) Wenn jetzt Unrat den Schulhof betrat, (3) schrie ... alles drauflos. (Noll, 1981) - (3) И теперь, (2) стоило Гнусу появиться на школьном дворе, (3) как икольники начинали орать... [(3) And now, (2) no sooner Gnus appeared in the schoolyard (3) than the schoolboys started yelling] (Galperina \& Kurella, 1963: 131).

- WHENEVER: (2) Wenn einmal Hans einen Blick erwischte, (3) war immer Spannimg und Neugier darin... (Seghers, 1951) - (3) ... но всякий раз, (2) как Ганс перехватывал чей-нибудь взгляд, (3) в нем светилось напряженное любопытство... [but (2) whenever Hans snatched someone's glance, (3) there was intense curiosity in it] (Kasatkina \& Stanevich, 1989: 530).

\section{4) Modus BARBARA (2)-(3) changes to modus CELARENT (2)-(3) (6 examples} in total):

a) a complex sentence with a correlate WHEN:

(2) ...Wenn der Gesang klappte, (3) ließ sie in Ruhe marschieren (Noll, 1981) - (2) Когда пели дружно, (3) их ме мучили на марше [(2) When they sang in concord, (3) they were not tormented on the march (Galperina \& Kurella, 1963). It is very interesting to comment on the procedure for restoring the "German" and "Russian" inferences. The minor premise (the subordinate conditional clause) (2) and the conclusion (the principal clause) (3) are represented by general affirmative judgments (A). Therefore, a "German" inference is constructed according to modus BARBARA $(\mathrm{A}, \mathrm{A}, \mathrm{A})$ : (1) (Soldiers) singing together in concord are left alone on the march. (2) 
They (the soldiers) sang in concord. (3) They were left alone. In the "Russian" enthymeme (2), the minor premise is also represented by a general affirmative judgment (A). During translation of the principal clause, representing (3) the conclusion of the enthymeme, "leave alone (= "not to torment") was substituted with an antonymous notion "torment". As a result of the antonymic translation, (3) the conclusion of the "Russian" enthymeme began to express a general negative judgment (E). If the minor premise is represented by a judgment of type (A), and the conclusion by a (E) type judgment, then the major premise should be a judgment of type (E). After restoring the missing major premise, the "Russian" inference can be constructed according to modus CELARENT (E,A,E): (1) [(Soldiers) singing together in concord are not tormented on the march]. (2) They (the soldiers) sang in concord. (3) They were not tormented on the march.

b) an asyndetic complex sentence:

(2) Wenn die einen zwischen die Hufe bekamen, (3) dann stampften sie einen kaputt. (Seghers, 1951) - (2) ...nопался им в лапы, (3) того они живьем не выпустят [they caught somebody in their clutches, (3) they will not let him go alive] (Kasatkina \& Stanevich, 1989: 322).

c) a simple sentence:

(2) Wenn solche Geschichten kursieren, (3) gefährdet man den Sieg. (Bredel, 1952) -

(2) Распространение таких историй (3) не способствует победе [The spread of such stories (3) does not contribute to victory] (Rosenthal, 1964: 96)

5) Along with these constructions, there are sentences with obvious deviations in the translation, where the inference is not retained.

The absence of inferences in translation is observed in the case when the causativeconsecutive semantic link, which is characteristic of the original text, is lost (4 examples in total). For instance: (2) Wenn er den hinter sich hat, (3) dann kommen vor allen Dingen mal zwei Jahre Kommiß. (Seghers, 1951) - ...a потом сельскохозяйственную повинность и еще два года воинской повинности [and then there will be agricultural conscription and two years of military conscription] (Kasatkina \& Stanevich, 1989: 397).

The main role in constructing logical inferences at the level of the German complex sentences belongs to the formal connectors of causative-consecutive relations. The comparative analysis showed that the "German" conditional conjunctions WENN, FALLS do not always find their full correspondence in the Russian translation.

Thus, during translation 354 "Russian" inferences were received from 358 "German" inferences of BARBARA modus, models (2)-(3), it means that the total number of Russian enthymemes decreased compared to German enthymemes. BARBARA modus was replaced by the CELARENT of the model (2)-(3) in six enthymemes. No inferences were retained in 4 sentences during translation. Deviations from the original text, made by the translators, occurred not only at the logical but also at the linguistic levels (a change in the syntactic structure of the German complex sentence). As regards the Russian variants of syntactic constructions that are represented in German by complex sentences with subordinate conditional clauses, there is a multivariate opportunity to express inferences:

a) in the form of complex sentences, in which the conditional conjunction WENN/FALLS is translated differently. The conjunctions IF and WHEN are most common; b) in the form of compound sentences; c) in the form of asyndetic complex sentences; d) in the form of two independent sentences; e) in the form of simple sentences; simple sentences of syllogisms, in turn, are represented in the Russian language as having prepositional substantive phrases, adverbial participial constructions, and participial constructions.

XLinguae, Volume 11, Issue 2, April 2018, ISSN 1337-8384, eISSN 2453-711X 
Thus, all complex sentences (syndetic and asyndetic ones) with subordinate conditional clauses (at the level of language) serve as a form of expressing the incomplete logical syllogisms - enthymemes - with the always missing major premise (at the level of logic). Therefore, the natural language "has developed such means for itself, which automatically, according to a given algorithm, lead to the elimination of one of the judgments of the syllogism - a major premise as the most common, wellknown judgment, entering the :general knowledge fund" of all speakers of a given language. These linguistic constructions (complex sentences) do not express anything else except for enthymemes; they allow the speaker to "save" the language form. In a word, the speaker expresses three inferences in a sentence, one of which, not existing in the material forms of the language (the major premise of the syllogism), is invented and guessed by the speaker and the hearer quite clearly on the background of two materially expressed forms of sentences in the form of the principal and subordinate clauses. In other words, the information not presented verbally entails neither a violation of the adequate understanding nor its loss in the listeners (speakers), because it is restored in their conceptual system.

\section{Discussion}

The data presented in the article can be considered only as a trend in the development of this topic, which requires further insight with other moduses, models and other syntactic constructions:

1. Comparative analysis of the methods for expressing logical inferences in the form of complex sentences with subordinate conditional clauses (altogether 2,107 examples) in the natural language (German and Russian) showed that in most cases the translation retains all the features of the linguistic expression of the thought of the original text language $(1,757-83 \%)$. Sentences with deviations were attributed to a group of sentences that do not express inferences $(350-17 \%)$. There were 276 such sentences in the German version). This could be explained by the fact that to transfer the same mental content there are the same mechanisms in different languages that allow using their language means in an adequate manner. This happens even in those cases when the language of the original text has a brightly expressed color which seems inexpressible in another language (translation). Translators are not constrained by the means of their own language, they use them freely.

2. The analysis showed that, in $4 \%$ of the inferences, the original modus changes during the translation process, which also indicates the deviations obtained during the translation process.

3. If the inference is retained in translation, it is built in the forms of the Russian language by the same rules as in the German language; the inference model is retained $(80 \%)$. In a number of cases, the model changes: (2) - (3) $\rightarrow$ (3) - (2); (3) - (2) $\rightarrow$ (2) (3); (2) - (3) $\rightarrow$ (3) - (2) - (3).

4. In $17 \%$ of cases, complex sentences, representing inferences, are left translated by the translators or are translated arbitrarily. This happens if:

- the original sentence expressing an inference is not translated completely, that is, either a minor premise (a conditional clause) or a conclusion (a principal clause) is eliminated during translation, therefore one judgement corresponds to the German inference in Russian;

- while retaining the general meaning of the statement in the translated equivalent, the semantic causative-consecutive dependence that characterizes the original text is lost.

5. Complex sentences, serving to express inferences in the German language, are most susceptible to changes in the translation process at the syntactic level: a wide variety of complex syntactic constructions of the Russian language correspond to the German complex sentence. The possibility to transform complex sentences during translation 
is primarily explained by the synonymy of these constructions, which are considered as linguistic variants that serve to express one logical-semantic invariant, that is, the causative-consecutive relations that underlie inferences. The use of various syntactic constructions in translation is permissible if a change in the syntactic structure does not lead to a change in semantics. But in most instances, the syntactic form of the original text is retained.

6. Conditional conjunctions of the German language WENN/FALLS are distinguished by a great variety when translated into Russian, depending on the types of sentences and can be translated as IF, WHEN, GIVEN, WHILE, ALTHOUGH, THAT, WHATEVER, NO SOONER THAN, AS SOON AS. Conjunctions IF and WHEN are used most frequently in translation.

\section{Conclusions}

Thus, in this article, a logical and linguistic analysis of complex sentences with subordinate conditional clauses in the natural language was carried out: one of the many problems of the relationship between language and thinking was investigated, namely, the expression of logical inferences by means of the German and Russian languages. These logical constructions acquire a variety of forms of linguistic expression in the natural language (on the basis of complex sentences with subordinate conditional clauses) that allow translators to express a certain thought with regard to their own abilities in terms of language proficiency. This study deals with literary translation, which reflects not only linguistic patterns but also other factors that depend on the individual skill of the translators and the creative tasks that confront them. The results of the analysis can be taken into account in the practice of teaching the translation of German texts into Russian, in the process of studying the peculiarities of language and style of the German-speaking authors of the $20^{\text {th }}$ century and of the well-known writers and translators, and also in compiling machine translation programs for literary texts. The novelty of the work is in the application of logical and linguistic analysis to the material of the literary text, on the basis of which the authors come to the conclusion that the analysis of the natural language by the methods of formal logic is possible and requires further careful study.

Having considered the inferences represented in the literary texts of the German and Russian languages, it can be concluded with certainty that the analysis of the natural language by the methods of formal logic is acceptable and admissible, has a positive dynamics, and stirs great interest as well. Numerous examples of inferences of only one BARBARA modus and only one grammatical construction (a complex sentence with a subordinate conditional clause) serve as evidence.

\section{Bibliographic references}

ABRAMOV, B.A. 2016. Theoretical grammar of the German language. Comparative typology of the German and Russian languages. Moscow: Yurayt Publishing House. ISBN: 978-5-9916-1452-8.

BABAITSEVA V.V. 2015. Syntax of the Russian language. Moscow: Flinta: Nauka. ISBN: 978-5-9765-2141-4.

BECHER, I.R. 1970. Abschied. Moscow: Khudozhestvennaya Literatura.ISBN: 9785-280-03558-4.

BECHER, J.R. 1950. Abschied. Moskau: Verlag für fremdsprachige Literatur.ISBN: 7119006592.

BEDNARSKAYA, L.V. 2015. Modern technologies of speech development. Moscow: Flinta: Nauka. ISBN: 978-5-9765-1942-8.

BENI, M.D. 2015. On logic, syntax, and silence.In: Studies in Logic Grammar and

XLinguae, Volume 11, Issue 2, April 2018, ISSN 1337-8384, eISSN 2453-711X 
Rhetoric, vol. 42, n. 55, pp.195-209. ISSN:0860-150X.

BREDEL, V. 1964. Sons. Translated by Rosenthal, R.A. Moscow: Khudozhestvennaya Literatura.ISBN: 978-5-280-03558-4.

BREDEL, W. 1952. Die Söhne. Moskau: Verlag für fremdsprachige Literatur. ISBN: 7119006592.

CHANG, F. - JANCIAUSKAS, M. - FITZ, H. 2012. Language adaptation and learning: Getting explicit about implicit learning. In: Linguistics and Language Compass, vol. 6, n.5, pp. 259-278.ISSN: 1749-818X.

DEKKER, P.J.E. 2015. Not Only Barbara. In: Journal of Logic Language and Information, vol. 24, n. 2, pp.95-129. ISSN:0925-8531.

DIATKA, C. - LIGUS, J. 2016. The contribution of teaching logic to ethical decision making. In: Communications, vol. 18, n. 4, pp. 123-128. ISSN 1335-4205.

DUBOIS, D. - PRADE, H. - SCHOCKAERT, S. 2017. Generalized possibilistic logic: Foundations and applications to qualitative reasoning about uncertainty. In: Toulouse University, Université Paul Sabatier, vol. 252, pp. 139-174.ISSN 00431354

EMETS, T.V. - URAZAEVA, N.R.- BARYSHNIKOVA, Y.V. 2017. Logical and linguistic problems: complex sentences from the position of formal logic. Tambov: Yukom Consulting Company LLC.ISBN: 2412-8988

EMETS, T.V. 2012. Introduction to linguistics. Magnitogorsk: Magnitogorsk State University Press.ISBN: 2222-9396

EVSTAFIADI, O.V. - BAYMURATOVA U.S. 2015. Complex conditional sentences in the "postcrossing" postcards.In:Bulletin of Kemerovo State University, vol. 1, n. 4, pp. 134-137.ISSN: 2078-8975.

FATTAKHOVA, N.N. 2015. Folk sayings: syntax and pragmatics. Moscow: Flinta: Nauka. ISBN 978-5-02-038596-2.

KELLERMANN, B. 1979. Die Stadt Anatol. Translated by Vershinina, Z.A. Moscow: Pravda. ISBN: 978-5-17-078336-6.

KELLERMANN, B. 1962. Die Stadt Anatol. Berlin: Verlag Volk und Welt. ISBN: 3746401461.

KRECHETNIKOV, K. - PESTEREVA, N. - RAJOVIĆ, G. 2016, Prospects for the Development and Internationalization of Higher Education in Asia. European Journal of Contemporary Education, Vol. 16, Is. 2, pp. 229-238. DOI: 10.13187/ejced.2016.16.229

KRIVONOSOV, A.T. 2012. Philosophy of language. Moscow-New York: “Azbukovnik" Publishing Center. ISBN: 978-5-911720-60-5.

KRIVONOSOV, A.T. 2017. Word and thought. Issues of interaction of language and thinking. Moscow-New York: The author's edition. ISBN 978-5-4465-1451-9.

MACKENZIE, J. 2014. From speech acts to semantics. Studies in Logic Grammar and Rhetoric. In: University of Bialystok, vol. 36, n. 49, pp.121-142. ISSN: 0860$150 X$.

MAHOWALD, K. - JAMES, A. - FUTRELL, R. - GIBSON, E. 2016. A metaanalysis of syntactic priming in language production.In:Journal of Memory and Language, vol. 91, n. 1, pp. 5-27. ISSN: 0749-596X.

GALPERINA, R.M. - KURELLA, V.N. 1963. Die Abenteuer des Werner Holt. Moscow: Khudozhestvennaya Literatura.ISBN: 978-5-280-03558-4.

NOLL, D. 1981. Die Abenteuer des Werner Holt. Berlin: Aufbau-Verlag.ISBN: 3351031009.

PAGNAN, R. 2013. Syllogisms in Rudimentary Linear Logic, Diagrammatically. Journal of Logic Language and Information. In: Springer Netherlands, vol. 22, n. 1, pp.71-113. ISSN: 0925-8531.

SEARLE, J.R. 2014.The structure and functions of language. Studies in Logic 
Grammar and Rhetoric.In: University of Bialystok, vol. 36, n. 49, pp.27-40. ISSN:0860-150X.

SEGHERS, A. 1951. Die Toten bleiben jung. Moskau: Verlag für fremdsprachige Literatur. [ISBN: 7119006592.

SZYMANIK, J. - VERBRUGGE, R. 2013. Logic and Cognition: Special Issue of Best Papers of the ESSLLI 2012 Workshop.In: Journal of Logic Language and Information, Springer Netherlands, vol. 22, no. 4, pp.357-362. ISSN: 0925-8531.

UHSE, B. 1969. Leutnant Bertram. Weimar: Aufbau-Verlag Berlin.ISBN: 3351031009.

TSVETKOVA, M.I. 2016, The Shadows of Reading: Reasons for the Bad Results of Bulgarians in PISA studies. European Journal of Contemporary Education, vol. 17, Is. 3, pp. 368-377. DOI: 10.13187/ejced.2016.17.311

VAN BENTHEM, J. 2014. Natural Language and Logic of Agency. In: Journal of Logic Language and Information, Springer Netherlands, vol. 23, n. 3, pp.367-382. ISSN: 0925-8531.

WOLF, S. (1960). Der geteilte Himmel. Leipzig: Verlag Leipzig. ISBN: 978-3934565-83-8

TYUNNIKOV, Y.S. 2016, Interrelation of Evaluation and Self-Evaluation in the Diagnostic Procedures to Assess Teachers' Readiness for Innovation. European Journal of Contemporary Education, Vol. 16, Is. 2, pp. 248-256. DOI: 10.13187/ejced.2016.16.248

ZAYATS, A.A. 2017. The ratio of formal logic and utterances of the natural language. In: The Eurasian Union of Scientists, vol. 5, n. 14, 637-643. ISSN: 24139335 .

Words: 7205

Characters: $50350(27,97$ standard pages $)$

Assoc. Prof. Tatiana V. Emets, PhD

Department of Romano-Germanic Philology and Translation,

Magnitogorsk State Technical University

26 Lenina Str.

455000 Magnitogorsk

Russia

t_emets@inbox.ru

Assoc. Prof. Iuliia V. Baryshnikova, PhD

Department of the English Language,

Magnitogorsk State Technical University,

26 Lenina Str.

455000Magnitogorsk

Russia

iuliiabaryshnikova@mail.ru

Assoc. Prof. Alexey Y. Trutnev, PhD

Department of Philosophy, Culturology and Social-Humanitarian Disciplines,

Magnitogorsk State Technical University,

26 Lenina Str.

455000 Magnitogorsk

Russia

trutnevalex83@yandex.ru

XLinguae, Volume 11, Issue 2, April 2018, ISSN 1337-8384, eISSN 2453-711X 
Assoc. Prof. Elena V. Suvorova, $\mathrm{PhD}$

Department of the Foreign Languages for Engineering,

Magnitogorsk State Technical University,

26 Lenina Str.

455000 Magnitogorsk

Russia

Elsuvorova1@bk.ru

Assoc. Prof. Tatiana L. Akhmetzyanova, $\mathrm{PhD}$

Department of the Foreign Languages for Engineering, Magnitogorsk State Technical University,

26 Lenina Str.

455000 Magnitogorsk

Russia

tanyaakhmetzaynova@inbox.ru 